\title{
Evaluation of Protein Nutritional Quality of Four Soybean Varieties Grown in Western Kenya
}

\author{
Fredrick B. Agengo ${ }^{1,2}$, Charlotte A. Serrem ${ }^{1} \&$ Florence W. Wamunga ${ }^{1}$ \\ ${ }^{1}$ Department of Family and Consumer Sciences, School of Agriculture and Biotechnology of the University of \\ Eldoret, Eldoret, Kenya \\ ${ }^{2}$ Department of Food Science and Technology, Faculty of Agriculture of the Jomo Kenyatta University of \\ Agriculture and Technology, Nairobi, Kenya \\ Correspondence: Fredrick B. Agengo, Department of Family and Consumer Sciences, School of Agriculture and \\ Biotechnology of the University of Eldoret, Eldoret, Kenya. Tel: 254-722-267-536. E-mail: \\ fagengo@yahoo.co.uk
}

Received: April 28, 2018

Accepted: May 18, $2018 \quad$ Online Published: July 12, 2018

doi:10.5539/jfr.v7n5p69

URL: https://doi.org/10.5539/jfr.v7n5p69

\begin{abstract}
Protein nutrition is important for human health because its deficiency leads to major public health problems such as Protein Energy Malnutrition. Soybean an excellent and cheap source of high quality protein has been introduced into the Western Kenya and other developing countries for improved health and food security, but end use qualities may reduce its utilization. The main objective of this study was to evaluate the protein nutritional quality of four soybean varieties grown in Western Kenya. Protein quality was determined using male weanling albino rats for the indices of net protein retention, food efficiency, apparent and true protein digestibilities and faecal weight. Soybean amino acid efficiency was evaluated using Protein digestibility corrected amino acid score (PDCAAS). Soybean diet SB 132 had the highest protein nutritional quality with the best protein retention of $6.29 \mathrm{~g}$, Apparent Protein digestibility of $89.13 \%$, True Protein Digestibility of $96.48 \%$, weight gain of $5.50 \mathrm{~g}$ and a Net Protein Retention Ratio of 4.70. All the four soybean varieties had high amino acid profiles with a Protein digestibility Corrected Amino Acid Score of 1.0. Soybean variety SB 132 is the most superior in digestibility and the study recommends its promotion as a food crop in Western Kenya and other developing countries for the management of Protein Energy Malnutrition and for food security.
\end{abstract}

Keywords: protein quality, digestibility, soybean, protein energy malnutrition, amino acid profile

\section{Introduction}

Protein nutrition is important for human health because its deficiency leads to major public health problems such as Protein Energy Malnutrition (PEM) (Muller \& Krawinkel, 2005). According to the United Nations International Children's Emergency Fund (UNICEF), PEM is currently one of the most widespread nutrition related health problems globally and in 2011 alone, 2.3 million Children died because they did not receive the nourishment they required (United Nations International Children's Emergency Fund [UNICEF], 2013). Protein which is one of three major macronutrients is an important source of calories and serves as the structural component of muscle and other tissues, hormones, enzymes and haemoglobin (Hoffman \& Falvo, 2004). Protein quality in food varies greatly and is dependent on the amino acid composition and digestibility (Cromwell, 2013).

Protein foods are either from plant or animal sources. Animal protein sources such as meat, milk and eggs are high quality because they contain all indispensable amino acids and have high digestibility (Hoffman \& Falvo, 2004). However, they are unaffordable for most people in developing countries, who live below the poverty line (Muller \& Krawinkel, 2005). Therefore, plants supply about $65 \%$ of the of the world's edible proteins, because they are cheaper, though the quality is poorer (Young \& Pellett, 1994). Legumes are the most important sources of plant proteins in the context of human protein nutrition. In addition, it has been established that compositing legume proteins with those from cereal and root crops has a complementation effect producing complete and well balanced amino acid profiles that meet human physiological requirements (Duranti, 2006).

Soybean (Glycine max (L) Merril), among legumes is unique because it is an important source of protein and oil 
(International Institute of Tropical Agriculture [IITA], 2009) and a good source of all indispensable amino acids (Karr-Lilienthal et al., 2006). Conversely, digestibility of soybean protein is reduced owing to the structure of legume proteins and certain anti-nutritional factors (Porres et al., 2002). For Instance, Giami (2002) reported a weight loss in rat groups fed on raw soybean samples and attributed this to the presence of toxic components such as growth inhibitors in the raw seeds while those fed on boiled soybean gained more weight compared to those fed on autoclaved diets. Different soybean varieties have been introduced and promoted in Western Kenya, however, because of the limited information available on their nutritional quality; there has been poor human utilization of these crops in different food formulations at household level with up to about $70-80 \%$ of soybean being consumed by the livestock industry (Government of Kenya [GoK], 2009). Therefore, the aim of the study was to evaluate the protein nutritional quality of four soybean varieties grown in Western Kenya by VLIR - UOS project.

\section{Material and Methods}

\subsection{Materials}

Four soybean grain varieties, SB 19, SB 25, SB 30 and SB 132, were obtained from Centro Internacional Agricultura Tropicale (CIAT), Maseno, Kenya. The grains had been grown in Siaya and Busia Counties of Western Kenya, planted during the short rains of September to December and the long rains of March to June growing seasons of the year 2012 - 2013. In addition, skimmed milk powder "Miksi" (Promasidor Kenya Ltd, Nairobi, Kenya) was used as the control. Other components included in the diet were mineral and vitamin mixtures "Amilyte" (Ultravetis East Africa Ltd, Nairobi Kenya), wheat bran (locally milled), white sugar (Mumias Sugar Company Ltd, Mumias - Kenya), corn flour "Zesta" (Trufoods (K) Ltd, Nairobi, Kenya) and corn oil "Elianto", (Bidco Oil Refineries, Thika, Kenya).

\subsection{Processing Soybean Grains}

Each of the four soybean varieties was separately soaked in distilled water for 24 hours, thereafter boiled for 180 minutes (Khetarpaul, Garg, \& Goyal, 2004), solar dried after draining off the water and later milled into flour using a commercial hammer mill (Powerline, BM-35, Kirloskar, India) with a $2 \mathrm{~mm}$ diameter mesh sieve. All the soybean samples were stored in airtight plastic containers at room temperature until required for use.

\subsection{Proximate Analyses}

Moisture content was determined using an oven (Model UNB 300 Schutzart, by Memmert GmbH \& Co. KG, Germany) drying procedure (Association of Official Analytical Chemists [AOAC] International, Method 925.09). Crude protein was determined by microKjeldahl method (AOAC International, Method 992.23). Crude fat content was determined using soxhlet extraction method (AOAC International, Method 920.29) using petroleum ether as solvent. Ash was determined by burning approximately $2 \mathrm{~g}$ food sample at $350-600^{\circ} \mathrm{C}$ for 6 hours in a muffle furnace (Carbolite $5302 \mathrm{AU}$, Bamford, Sheffield, England) (AOAC International, Method 923.03) to constant weight (Association of Official Analytical Chemists [AOAC], 1995) and the carbohydrate content by subtracting the sum of weights of protein, lipid, ash and moisture from the total wet matter basis (Food and Agriculture Organizaation [FAO], 2003).

\subsection{Evaluation of Protein Quality}

\subsubsection{Animals and Housing}

Twenty four (24) weanling male albino rats of between 5 to 7 weeks old were obtained from the zoology department of the University of Eldoret, Kenya. The initial weight of the rats was between $94 \mathrm{~g}$ and $145 \mathrm{~g}$. They were housed in individual cages with wire bottomed screens to separate the faecal materials (Figure 1). An alternating 12-hour light/dark cycle with mean temperature of between $22^{\circ} \mathrm{C}$ and $25^{\circ} \mathrm{C}$ and humidity conditions of between $40 \%$ and $60 \%$ was maintained. The rats' maintenance was conducted in accordance with the US National Research Council Guide for the Care and Use of Laboratory Animals (National Research Council [NRC], 2011). 


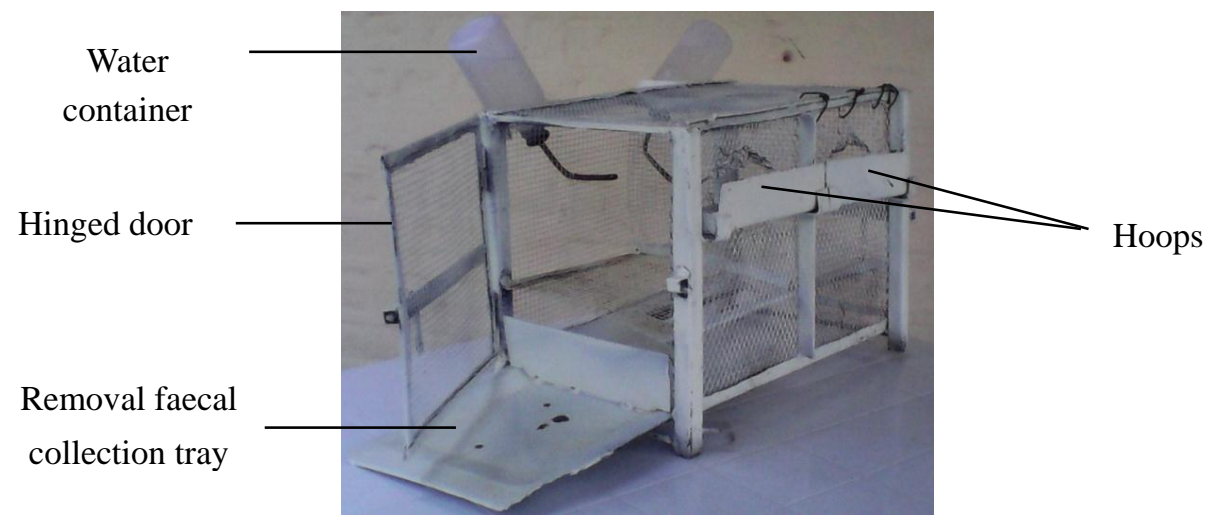

Figure 1. Rat cage

\subsubsection{Diet Formulation}

Formulation of diets was done according to AOAC International (2000), method 960.48 with modifications. A total of six diets were prepared and used in the study (Table 2). The first four diets were prepared from the flour obtained after boiling, drying and milling of soybean varieties SB 19, SB 25, SB 30 and SB 132. Based on their proximate composition (Table 1), the diets were made isonitrogenous by adjusting their protein contents to $10 \%$. The fifth was the control or reference diet (Skimmed milk powder) that was prepared according to the procedure described by Chapman, Castillo and Campbell (1959). The sixth was the protein free diet that was used to determine the endogenous nitrogen excretion. The diets were also made to supply adequate nutrients by incorporating $(1 \%)$ vitamin, $(1 \%)$ cellulose and $(5 \%)$ minerals. The soybean and powdered milk were incorporated into the basal (protein-free) diet at the expense of the sucrose: corn starch mixture of 50:50 to bring the diet composition to $100 \%$. The fat content in all the diets was adjusted to $9 \%$ using corn oil. To prepare each of the diets, all the dry ingredients were mixed thoroughly for 10 minutes using a Kenwood food mixer (Kenwood chef KMC200, Kenwood Co. Ltd, United Kingdom) operated at medium speed to ensure even distribution. Oil was then added and the diets mixed again for 10 minutes. Each diet was then packed in a separate zip lock plastic bag and stored at $4^{0} \mathrm{C}$ in a refrigerator. Before feeding, the calculated amount of dry feed for a diet per day for each rat was mixed with $5 \mathrm{~g}$ of distilled water to wet the feed to make it easier for the rats to consume.

Table 1. Proximate composition of the four soybean varieties used to calculate the diets

\begin{tabular}{lccccc}
\hline Diet & Protein (\%) & Fat (\%) & Moisture (\%) & Ash (\%) & Carbohydrate (\%) \\
\hline SB 19 & 35.2 & 17.8 & 10.2 & 5.3 & 31.5 \\
SB 25 & 35.5 & 18.7 & 10.5 & 5.2 & 30.2 \\
SB 30 & 34.6 & 17.5 & 11.0 & 5.2 & 31.8 \\
SB 132 & 36.7 & 21.8 & 10.2 & 5.3 & 26.0 \\
\hline
\end{tabular}

Table 2. Formulation of Experimental diets

\begin{tabular}{lcccccc}
\hline Ingredients & \multicolumn{7}{c}{ Diet composition $(\mathbf{g})$} \\
\cline { 2 - 7 } & SB 19 & SB 25 & SB 30 & SB 132 & Protein free diet & Skimmed milk powder \\
\hline SB 19 & 284.4 & 0 & 0 & 0 & 0 & 0 \\
SB 25 & 0 & 282 & 0 & 0 & 0 & 0 \\
SB 30 & 0 & 0 & 289.44 & 0 & 0 & 0 \\
SB 132 & 0 & 0 & 0 & 272.4 & 0 & 0 \\
Skimmed milk powder & 0 & 0 & 0 & 0 & 0 & 333.3 \\
Corn oil & 90 & 90 & 90 & 90 & 90 & 90 \\
Mineral mix & 50 & 50 & 50 & 50 & 50 & 50 \\
Vitamin mix & 10 & 10 & 10 & 10 & 10 & 10 \\
Cellulose & 10 & 10 & 10 & 10 & 10 & 10 \\
Sucrose & 277.8 & 279 & 275.28 & 283.80 & 420 & 253.35 \\
Corn flour & 277.8 & 279 & 275.28 & 283.80 & 420 & 253.35 \\
\hline
\end{tabular}


Skimmed milk powder (Miksi, by promasidor (Kenya) Ltd, Nairobi), mineral and vitamin mixtures (Amilyte, Manufactured by Ultravetis East Africa Ltd, Nairobi Kenya), wheat bran (locally milled), sucrose (Mumias Sugar Company Ltd, Mumias - Kenya), corn flour (Zesta, Manufactured by Trufoods (K) Ltd, Nairobi Kenya) and corn oil (Elianto, Manufactured by Bidco oil refineries, Thika Kenya).

\subsubsection{Acclimatization}

The rats were acclimatized for an initial period of 4 days from $27^{\text {th }}$ February to $2^{\text {nd }}$ March 2014 and during this times the rats were fed on standardized laboratory irradiated rat pellets (Hindustan Animal Feeds, Gujarat, India) provided on a ratio of 1:1 with the formulated diets for the first 3 days ( $27^{\text {th }}$ February to $1^{\text {st }}$ of March 2014). This was meant to provide each rat with a $15 \mathrm{~g}$ daily meal. On the last day of acclimatization ( $2^{\text {nd }}$ of March 2014) the rats were put on the formulated diets that went all through to the digestibility period of the study.

\subsubsection{Digestibility Study}

Rats were grouped by Complete Randomized Design into six (6) groups based on the rat's weights with mean weight per group not differing by more than $8 \mathrm{~g}$. This was caused by the wide variation in rat weights as there was a shortage from the supplier. The first four groups were fed on diets made from different varieties of soybean. The fifth group was on a protein-free diet and the sixth group was fed on the control or reference diet (Skimmed milk powder) with each rat being provided $15 \mathrm{~g}$ of the diet ad libitum on a daily basis during the study period. Foods that remained on the feeding trays at the end of the day was collected and weighed to determine the amount of food that had been consumed. Clean water was provided during the entire study period. Protein digestibility study lasted for 5 days from $3^{\text {rd }}$ to $7^{\text {th }}$ March 2014, of which faeces from each rat was collected in polyethylene bags on a daily basis and frozen at $-20^{\circ} \mathrm{C}$ until required. Each rat's daily records for food consumption and weight gain or loss were recorded and used to calculate the net protein retention ratio (NPRR), food efficiency ratio (FER), food intake, protein intake and body weight gain or loss.

\subsubsection{Faecal Analyses}

The total faeces from each rat were collected and dried overnight at $100^{\circ} \mathrm{C}$ in an air circulation oven, weighed and ground using laboratory mortar and pestle. Faeces from each group of four rats fed the same diet were pooled. Nitrogen in the faeces was determined by microKjeldahl method (AOAC International, 1995) Method 992.23 (Section 2.3). The faecal material of the rat group that was fed the protein free diet was used to calculate the endogenous nitrogen losses. Apparent protein digestibility (APD), faecal protein and true protein digestibility (TPD) were computed from the faecal nitrogen and nitrogen intake of the test diet.

\subsection{Protein Digestibility Corrected Amino Acid Score (PDCAAS) Determination}

The PDCAAS is the official method for predicting protein quality for food based on human amino acid requirements (FAO, 2007). The parameters considered are essential amino acid profile of the test protein and ability to supply the amino acid in sufficient quantity. Indispensable amino acid profiles for the soybean were obtained from United States Department of Agriculture [USDA] (2013). In this study, amino acid composition data for the test product and true digestibility values were used to compute the PDCAAS using the following equation (FAO, 2007):

$$
\text { Amino acid score }=\frac{\mathrm{mg} \text { of amino acids in } 1 \mathrm{~g} \text { test protein }}{\mathrm{mg} \text { of amino acid in requirement pattern }}
$$

Amino acid scores for 9 indispensable amino acids, Histidine, Isoleucine, Leucine, Lysine, Methionine, Phenylalanine, Threonine, tryptophan and Valine were computed using a human pattern for amino acid requirements for (1 to 2), (3 to 10), (11 to 14), (15 to 18) and 18 and above years (FAO, 2007).

\subsection{Data Analysis}

All the experiments were performed in triplicate and the results presented as mean values and standard. Digestibility values for each diet were statistically analyzed using linear model procedures and the significant differences considered at $\mathrm{P}<0.05$.

\section{Results and Discussion}

\subsection{Protein Digestibility}

Food intake of the protein free diet was less by 19\% compared to the control and soybean diets (Table 3). Differences in the food intake among different rat groups might have been influenced by the nutrient quality of each diet. Food consumed in greater quantities than the other must have been more palatable 
(Erlanson-Albertsson, 2005). The low food intake may be due to the presence of unpalatable components and deficiencies in certain indispensible amino acids, minerals and vitamins, leading to nutrient imbalance (Porres et al., 2002). Following similar studies, Mosha and Bennink (2004) attributed suppressed food intake to an imbalance of dietary protein. While Serrem, de Kock, Oelofse and Taylor (2011) concluded that high food intake is influenced by the type and quantity of protein in a diet.

Protein intake of soybean diet SB 19 was 3.4\% less compared to the control diet. Similarly, diets SB 25 and 132 were $2 \%$, respectively higher than the control diet (Table 3). Protein intake is critical for growth such that its deficiency leads to a reduction in growth, muscular wasting, emaciation and even death (Serrem et al., 2011). Protein intake is believed to be influenced by the quantity, availability and nature of the indispensible amino acids present in the diet (Khan, 2009).

The faecal weight of the rat group fed on soybean diet SB 30 was 29\%, 40\%, 19\% and 25\% higher than control diet and soybean diets SB 19, SB 25 and SB 132 respectively (Table 3). High faecal bulk may be explained by a large amount of unabsorbed residue in the diet that elicits more faecal excretion. Serrem et al. (2011) attributed higher faecal weights to the effects of enzyme - resistant starch and thermal processing of the test foods in diets. Similarly, diets may differ in their potential to increase fecal weights even when they contain identical amounts of total dietary fibre (Ranhotra, Gelroth, Glaser, \& Rag, 1991).

Faecal protein among the rats fed on the soybean diets was high in diet SB 30 and low in diet SB 19 and SB 132, and the control diet, showing that the latter three retained higher quantities of protein (Table 3). The higher faecal protein excretion in soybean diet SB 30 shows that less protein was absorbed. Also, it could be a result of increased microbial activity in the intestine, utilizing indigestible carbohydrates and proteins from the beans substrate (Serrem et. al., 2011). Higher retention may be due to lower levels of anti-nutritional factors, hence more digestible protein increasing the protein retained (Fang, 2013). It has also been suggested by Karalazos (2007) that there is a positive effect with increased dietary lipid in improving protein retention.

Table 3. Food and protein intake and faecal weight, faecal protein and protein retention

\begin{tabular}{|c|c|c|c|c|c|c|}
\hline \multirow[t]{2}{*}{ Diets } & \multirow{2}{*}{$\begin{array}{c}\text { Food } \\
\text { intake }(\mathrm{g})\end{array}$} & \multirow{2}{*}{$\begin{array}{c}\text { Protein } \\
\text { intake (g) }\end{array}$} & \multirow{2}{*}{$\begin{array}{c}\text { Faecal } \\
\text { weight }(g)\end{array}$} & \multicolumn{2}{|c|}{ Faecal protein } & \multirow{2}{*}{$\begin{array}{c}\text { Protein } \\
\text { retention }(\mathrm{g})\end{array}$} \\
\hline & & & & (g) & $(\%)$ & \\
\hline SB19 & $62.25^{\mathrm{b}} \pm 3.69$ & $6.23^{\mathrm{b}} \pm 0.37$ & $2.36^{\mathrm{d}} \pm 0.21$ & $0.26^{\mathrm{c}} \pm 0.02$ & $4.11^{\mathrm{c}} \pm 0.04$ & $5.97^{\mathrm{b}} \pm 0.35$ \\
\hline $\mathrm{SB}$ & 65.75 & $6.58^{\mathrm{a}} \pm 0.15$ & $3.18^{\mathrm{b}} \pm 0.39$ & $0.31^{\mathrm{b}} \pm 0.01$ & $4.63^{\mathrm{b}} \pm 0.10$ & $6.27^{\mathrm{ba}} \pm 0.14$ \\
\hline SB30 & $65.25^{\mathrm{ba}} \pm 2.06$ & $6.53^{\mathrm{ba}} \pm 0.21$ & $3.95^{\mathrm{a}} \pm 0.20$ & $0.36^{\mathrm{a}} \pm 0.01$ & $5.45^{\mathrm{a}} \pm 0.01$ & $6.17^{\mathrm{ba}} \pm 0.19$ \\
\hline SB132 & $65.50^{\mathrm{a}} \pm 2.08$ & $6.55^{\mathrm{a}} \pm 0.21$ & $2.98^{\mathrm{bc}} \pm 0.02$ & $0.26^{\mathrm{c}} \pm 0.01$ & $4.08^{\mathrm{c}} \pm 0.02$ & $6.29^{\mathrm{a}} \pm 0.20$ \\
\hline SMP & $64.50^{\mathrm{ba}} \pm 1.73$ & $6.45^{\mathrm{ba}} \pm 0.17$ & $2.80^{\mathrm{c}} \pm 0.11$ & $0.23^{\mathrm{d}} \pm 0.01$ & $3.59^{\mathrm{d}} \pm 0.12$ & $6.22^{\mathrm{ba}} \pm 0.17$ \\
\hline PFD & $52.00^{\mathrm{c}} \pm 0.82$ & $0.00^{\mathrm{c}} \pm 0.00$ & $0.73^{\mathrm{e}} \pm 0.04$ & $0.00^{\mathrm{e}} \pm 0.00$ & $2.71^{\mathrm{e}} \pm 0.07$ & $0.00^{\mathrm{c}} \pm 0.00$ \\
\hline
\end{tabular}

Values are means \pm standard deviations. Values followed by the same letter superscripts in the same column are not significantly different at $(\mathrm{p}<0.05)$ as assessed by Least Significant Difference.

SMP - Skimmed Milk Powder

PFD - Protein Free Diet

\subsection{Protein Nutritional Quality}

Food Efficiency Ratio (FER) of the protein free diet was negative. A higher FER was observed among the rats that were fed on the control diet which was $6 \%$ greater than that of soybean diet SB 132 (Table 4). A lower FER value of the protein free diet might have resulted from a lower food intake and weight loss (Baskaran, Malleshi, Jayaprakashan, \& Lokesh, 2001). Similarly, a higher FER was perhaps due to high food intake levels (Serrem et al., 2011). Previously, Baskaran et al. (2001) established that there was a higher FER value among rats that were fed on the control diet. A higher FER is an important quality attribute of the supplementary foods with high dietary bulk (Serrem et al., 2011).

Apparent protein digestibility (APD) of the control and soybean diet were high ( $84 \%$ and above) with only slight difference between the diets (Table 4). This might have been due to the ability of the protein in the control and soybean diets to meet the metabolic demand for amino acids (Boye, Wijesinha-Bettoni, \& Burlingame, 2012). Studies have assessed APD values and reported results similar to those of the present study. For example, Fang (2013) reported APD values in the range of $63.4 \%$ and $95.4 \%$ in soybean. Similarly, Siccardi III (2006) found out APD values of between $89.9 \%$ and $96.9 \%$ in soybean that compared well with those reported in soybean diet SB 132. 
True Protein Digestibility (TPD) value was highest for the control diet but with only slight variation from the soybean diets (Table 4). The TPD value in the control and the soybean diet may be attributed to the presence of substantial quantities of essential amino acids in the diets (Khan, 2009). A previous study by Jackson (2009) reported TPD for legumes and control diet of between 62.6 to $98.1 \%$, respectively. The TPD value observed in the present investigation shows that the soybean varieties had high protein digestibility, an indication that they can be used to improve the protein quality of diets to fulfill nutritional requirements for growth and maintenance.

Weight gain was high in the rats fed on the control diet which was similar to that of the rats fed on soybean diet SB 132 while the rats fed on the protein free diet lost weight. Among the soybean diets, the least weight gain was observed in the rat group fed on diet SB 30 (Table 4). The increased weight gain of rats fed on a positive nitrogen balanced diet might have been due to a more highly digestible protein that promoted a higher weight gain in the test animals (Fang, 2013) while the drastic weight loss in the rats fed on the basal diet was due to the inadequacy in quality and quantity of the dietary protein (Serrem et al., 2011). Mosha and Bennink (2004) noted that rats fed on a maize meal only diet lost weight. Similarly, Serrem et al. (2011) also reported that rats fed on $100 \%$ sorghum biscuits did not gain weight during the 5 days of a digestibility study.

Net protein retention ratio (NPRR) of the control diet and soybean diet SB 132 were quite similar (Table 4). The proteins from skimmed milk powder and soybean diets performed better and as such were reflected in the positive weight gain response of the test animals. An earlier study by Qayyum (2012) has reported NPRR values of 2.21 to 3.48 among different legume varieties. The NPRR is an indicator of protein quality that takes into account the weight loss of the rats on the protein free diet in contrast to the protein efficiency ratio (Food and Agriculture Organization [FAO]/World Health Organization [WHO], 1991).

Table 4. Indices of protein quality for the four soybean varieties grown in Western Kenya

\begin{tabular}{lllllll}
\hline \multicolumn{1}{c}{ Indices } & \multicolumn{1}{c}{ SB 19 } & \multicolumn{1}{c}{ SB 25 } & \multicolumn{1}{c}{ SB 30 } & \multicolumn{1}{c}{ SB 132 } & \multicolumn{1}{c}{ SMP } & \multicolumn{1}{c}{ PFD } \\
\hline FER & $0.060^{\mathrm{bc}} \pm 0.02$ & $0.061^{\mathrm{bac}} \pm 0.02$ & $0.038^{\mathrm{c}} \pm 0.01$ & $0.085^{\mathrm{ba}} \pm 0.02$ & $0.090^{\mathrm{a}} \pm 0.01$ & $-0.105^{\mathrm{d}} \pm 0.02$ \\
APD (\%) & $88.37^{\mathrm{b}} \pm 0.04$ & $87.40^{\mathrm{c}} \pm 0.32$ & $84.21^{\mathrm{d}} \pm 0.07$ & $89.13^{\mathrm{a}} \pm 0.07$ & $88.06^{\mathrm{b}} \pm 0.49$ & $0.00^{\mathrm{e}} \pm 0.00$ \\
TPD (\%) & $96.14^{\mathrm{b}} \pm 0.15$ & $94.85^{\mathrm{c}} \pm 0.47$ & $92.12^{\mathrm{d}} \pm 0.14$ & $96.48^{\mathrm{b}} \pm 0.10$ & $97.17^{\mathrm{a}} \pm 0.68$ & $0.00^{\mathrm{e}} \pm 0.00$ \\
BW gain/loss (g) & $3.75^{\mathrm{bc}} \pm 0.96$ & $4.25^{\mathrm{ba}} \pm 1.50$ & $2.50^{\mathrm{c}} \pm 0.58$ & $5.50^{\mathrm{a}} \pm 1.29$ & $5.75^{\mathrm{a}} \pm 0.96$ & $-5.25^{\mathrm{d}} \pm 0.96$ \\
NPRR & $2.90^{\mathrm{bc}} \pm 0.85$ & $3.45^{\mathrm{ba}} \pm 1.60$ & $1.69^{\mathrm{c}} \pm 0.65$ & $4.70^{\mathrm{a}} \pm 1.38$ & $4.93^{\mathrm{a}} \pm 1.07$ & $0.00^{\mathrm{d}} \pm 0.00$ \\
\hline
\end{tabular}

Values are means \pm standard deviations. Values followed by the same letter superscripts in the same row are not significantly different at $(\mathrm{p}<0.05)$ as assessed by Least Significant Difference. 
Table 5. Comparison of amino acid composition ( $\mathrm{mg} / \mathrm{g}$ protein) of diet protein sources with WHO requirement pattern for children, adolescents and adults

\begin{tabular}{|c|c|c|c|c|c|c|c|c|c|c|}
\hline \multirow{2}{*}{ Amino acids } & \multicolumn{5}{|c|}{ USAD, 2013} & \multicolumn{3}{|c|}{ FAO, 2011 (Years) } & \multirow[b]{2}{*}{ 15-18 } & \multirow[b]{2}{*}{$\geq 18$} \\
\hline & SMP & SB 19 & SB 25 & SB 30 & SB 132 & 1-2 & 3-10 & 11-14 & & \\
\hline Histidine & 27.13 & 24.6 & 24.6 & 24.6 & 24.6 & 18 & 16 & 16 & 16 & 15 \\
\hline Isoleucine & 60.51 & 44.3 & 44.3 & 44.3 & 44.3 & 31 & 30 & 30 & 30 & 30 \\
\hline Leucine & 97.95 & 74.4 & 74.4 & 74.4 & 74.4 & 63 & 61 & 61 & 60 & 59 \\
\hline Lysine & 79.31 & 60.8 & 60.8 & 60.8 & 60.8 & 52 & 48 & 48 & 47 & 45 \\
\hline Methionine + Cysteine & 34.32 & 27.04 & 27.04 & 27.04 & 27.04 & 25 & 23 & 23 & 23 & 22 \\
\hline Phenylalanine + Tyrosine & 96.58 & 82.22 & 82.22 & 82.22 & 82.22 & 46 & 41 & 41 & 40 & 38 \\
\hline Threonine & 45.13 & 39.68 & 39.68 & 39.68 & 39.68 & 27 & 25 & 25 & 24 & 23 \\
\hline Tryptophan & 14.10 & 13.28 & 13.28 & 13.28 & 13.28 & 7 & 6.6 & 6.6 & 6.3 & 6.0 \\
\hline Valine & 66.92 & 45.61 & 45.61 & 45.61 & 45.61 & 41 & 40 & 40 & 40 & 39 \\
\hline Protein content & 36.16 & 37.80 & 37.80 & 37.80 & 37.80 & & & & & \\
\hline Total & 558.11 & 449.73 & 449.73 & 449.73 & 449.73 & 310 & 290.6 & 290.6 & 286.3 & 277 \\
\hline TPD (\%) & 97.17 & 96.48 & 94.85 & 92.12 & 96.48 & & & & & \\
\hline Limiting AA (1 -2yrs) & None & None & None & None & None & & & & & \\
\hline Limiting AA (3 -10yrs) & None & None & None & None & None & & & & & \\
\hline Limiting AA (11 -14yrs) & None & None & None & None & None & & & & & \\
\hline Limiting AA (15 -18yrs) & None & None & None & None & None & & & & & \\
\hline Limiting AA ( $\geq 18$ yrs) & None & None & None & None & None & & & & & \\
\hline Lysine Score (1-2yrs) & 1.53 & 1.17 & 1.17 & 1.17 & 1.17 & & & & & \\
\hline Lysine Score $\quad(3-10 y r s)$ & 1.64 & 1.27 & 1.27 & 1.27 & 1.27 & & & & & \\
\hline Lysine Score (11-14yrs) & 1.65 & 1.27 & 1.27 & 1.27 & 1.27 & & & & & \\
\hline Lysine Score (15-18yrs) & 1.68 & 1.29 & 1.29 & 1.29 & 1.29 & & & & & \\
\hline Lysine Score $\quad(\geq 18$ yrs) & 1.76 & 1.35 & 1.35 & 1.35 & 1.35 & & & & & \\
\hline PDCAAS (1-2 yrs) & 1.0 & 1.0 & 1.0 & 1.0 & 1.0 & & & & & \\
\hline PDCAAS (3-10 yrs) & 1.0 & 1.0 & 1.0 & 1.0 & 1.0 & & & & & \\
\hline PDCAAS (11 -14 yrs) & 1.0 & 1.0 & 1.0 & 1.0 & 1.0 & & & & & \\
\hline PDCAAS (15 -18 yrs) & 1.0 & 1.0 & 1.0 & 1.0 & 1.0 & & & & & \\
\hline PDCAAS ( $\geq 18$ yrs) & 1.0 & 1.0 & 1.0 & 1.0 & 1.0 & & & & & \\
\hline
\end{tabular}

Indispensible amino acid scores were obtained from the USDA (2013). Amino acid reference pattern for children, adolescents and adults (FAO, 2011) Skimmed milk powder "Miksi" (Promasidor Kenya Ltd, Nairobi, Kenya).

Performance of the skimmed milk powder (Control diet) and soybean diets in the present study have shown they probably have indispensable amino acid pattern considered adequate (Table 5) based on the scoring pattern recommended for judging protein quality in children, adolescents and adults (FAO/WHO, 1991). Other researchers have also conducted similar studies on legumes and used PDCAAS index to provide information about the potential of plant protein sources. For example, Singh, Kumar, Sabapathy and Bawa (2008) reported acceptable PDCAAS values of 0.92 for soybean protein isolate and 0.99 for soybean protein concentrate. Messina (1999) also noted that PDCAAS of legumes imparts reasonably good protein with improved digestibility.

\section{Conclusions}

All the four selected soybean varieties have superior protein quality with high Apparent and True Digestibilities and Protein Digestibility Corrected Amino Acid Scores of above 1.0 and can supply protein comparable to animal source to individuals of all age groups in Western Kenya. Soybean variety SB132 is the most superior in digestibility and the study recommends its promotion as a food crop in Western Kenya and other developing countries for the management of Protein Energy Malnutrition and for food security.

\section{Acknowledgment}

I am very grateful to the Almighty God for His mercy and grace that has brought me this far. My special thanks go to VLIR - UOS project for funding my studies. I also want to extend my thanks to Edwin Kirwa, Apollo and not forgetting all other persons not mentioned here who in one way or another contributed directly or indirectly to the success of my studies. Fredrick Agengo says thank you. 


\section{References}

AOAC. (1995). Official methods of analysis (16 ${ }^{\text {th }}$ Ed.). Washington, DC: Association of Official Analytical Chemists.

AOAC. (2000). Official methods of analysis ( $17^{\text {th }}$ Ed.). Washington, DC: Association of Official Analytical Chemists.

Baskaran, V., Malleshi, M. N., Jayaprakashan, S. G., \& Lokesh, B. R. (2001). Biological evaluation for protein quality of the supplementary foods based on popped cereals and legumes suitable for feeding rural mothers and children in India. Journal of Plant food for human nutrition, 56, 37-49. https://doi.org/10.1023/A:1008169011109

Boye, J., Wijesinha-Bettoni, R., \& Burlingame, B. (2012). Protein quality evaluation twenty years after the introduction of the protein digestibility corrected amino acid score method . British Journal of Nutrition, 108, S183-S211. https://doi:10.1017/S0007114512002309

Chapman, D. G., Castillo, R., \& Campbell, J. A. (1959). Evaluation of protein in foods, I: A method for the determination of the protein efficiency ratio. Can. J. Biochem. Physiol, 37, 679-686. https://doi.org/10.1139/o59-074

Cromwell, G. L. (2013). Soybean Meal - An Exceptional Protein Source. Animal and Food Sciences Department - University of Kentucky. Retrieved from https://en.engormix.com/feed-machinery/articles/soybean-meal-exceptional-protein-t40451.htm

Duranti, M. (2006). Grain legume proteins and nutraceutical properties. Fitoterapia, 77, 67-82. https://doi.org/10.1016/j.fitote.2005.11.008

Erlanson-Albertsson, C. (2005). How Palatable Food Disrupts Appetite Regulation. Basic and Clinical Pharmacology and Toxicology, 97, 61-73. https://doi.org/10.1111/j.1742-7843.2005.pto_179.x

Fang, X. (2013). Evaluation of soybean meal from selected cultivars of soybeans for use in practical diets for L.vannamei. (Masters thesis - Auburn University - Alabama). Retrived from $\mathrm{http}: / / \mathrm{www} . a g . a u b u r n . e d u / f i s h / w p-c o n t e n t / u p l o a d s / f o r m i d a b l e / X i a o y u n-t h e s i s-s u b m i t . p d f$

FAO. (2003). Food energy - Methods of analysis and conversion factors. Rome - Italy: Food and Agriculture Organization.

FAO. (2007). Nutritional Status of the Children: Assessment of Malnutrition in Third World Countries. Rome Italy: FAO Bulletin. No - 24. Pp 12-34.

FAO/WHO. (1991). Protein quality evaluation. FAO food and nutrition paper 51. Rome - Italy: Food and Agriculture Organization of the United Nations.

Giami, S. Y. (2002). Chemical composition and nutritional attributes of selected newly developed lines of soybean (Glycine max (L) Merr). J. Sci. Food Agri., 82, 1735-1739. https://doi.org/10.1002/jsfa.1239

GoK. (2009). Soybean Production and Marketing Strategy. Nairobi, Kenya: Government of Kenya.

Hoffman, J. R., \& Falvo, M. (2004). Protein - which is best? Journal of Sports Science and Medicine, 3, 18-130. https://www.jssm.org

IITA. (2009). Cereals and Legumes Systems: Research For Development. Retrieved from www.iita.org.

Jackson, J. C. (2009). Protein nutritional quality of cowpea and navy bean residue fractions. Afr. J. Food Agric. Nutr., 9(2), 764-778. ISSN. 1684-5374

Karalazos, V. (2007). Sustainable alternatives to fish meal and fish oil in fish nutrition: Effects on growth, tissue fatty acid composition and lipid metabolism. (Doctoral thesis) Institute of Aquaculture, University of Stirling, Stirling, Scotland. Retrived from http://www.storre.stir.ac.uk/bitstream/1893/220/1/karalazos\%20vasilis\%20-\%20PhD\%20thesis.pdf

Karr-Lilienthal, L. K., Baruer, L. L., Utterback, P. L., Zinn, K. E., Frazier, R. L., ... Parsons, C. M. (2006). Chemical composition and nutritional quality of soybean meals prepared by extruder/expeller processing for use in poultry diet. J. Ag. Food Chem., 54, 8108-14. https://doi:0.1021/jf061425t

Khan, M. I. (2009). Utilization of soybean as a functional food. Unpublished Doctoral thesis - National Institute of Food Science \& Technology, University of Agriculture Faisalabad - Pakistan

Khetarpaul, N., Garg, R., \& Goyal, R. (2004). Improvement in cooking quality of soybean (Glycine max) by 
presoaking treatment with enzyme (lipase) solution. Nutr. Food Sci., 34, 8-12. https://doi.org/10.1108/00346650410516153

Messina, M. J. (1999). Legumes and soybeans: overview of their nutritional profiles and health effects. Am J Clin Nutr., 70, 439-450. https://doi: 10.1093/ajcn/70.3.439s

Mosha, T. C., \& Bennink, M. R. (2004). Protein quality of drum-processed cereal-bean-sardine composite supplementary foods for pre-school age children. J Sci Food Agric., 84, 111-1118. https://doi.org/10.1002/jsfa.1756

Muller, O., \& Krawinkel, M. (2005). Malnutrition and health in developing countries. CMAJ, 173(3), 279-284. https://doi: 10.1503/cmaj.050342

NRC. (2011). Guide for the Care and Use of Laboratory Animals: National Academy of Sciences. Washington: National Research Council.

Porres, J. M., Urbano, G., Fernandez-Figares, I., Prieto, C., Perez, L., \& Aguilera, J. F. (2002). Digestive utilization of protein and amino acids from raw and heated lentils by growing rats. Journal of the Science of Food and Agriculture, 82, 1740-1747. https://doi.org/10.1002/jsfa.1251

Qayyum, M. M. N. (2012). Characterization and bio-evaluation of some indigenous legume protein isolates for complementary foods. Unpublished Doctoral thesis - National Institute of Food Science \& Technology, University of Agriculture Faisalabad - Pakistan

Ranhotra, G. S., Gelroth, J. A., Glaser, B. K., \& Rag, C. S. (1991). Fecal Bulking Effect of Whole Grain Flour from Selected Grains. American Association of Cereal Chemists, Cereal Chemistry, 68(5), 556-558. http://www.aaccnet.org/publications/cc/backissues/1991/Documents/68_556.pdf

Serrem, C. A., de Kock, H. L., Oelofse, A., \& Taylor, J. R. (2011). Rat bioassay of the protein nutritional quality of soy fortified sorghum biscuits for supplementary feeding of school-age children. Department of Food Science, University of Pretoria. South Africa, 1-26.

Siccardi III, A. J. (2006). Daily digestible protein and energy requirements for growth and maintenance of sub-adult pacific white shrimp (Litopenaeus vannamei). Doctoral thesis (Texas A and M University. Retrived from http://oaktrust.library.tamu.edu/bitstream/handle/1969.1/ETD-TAMU-1832/SICCARDI-DISSERTATION.p df? sequence $=1$

Singh, P., Kumar, R., Sabapathy, S. N., \& Bawa, A. S. (2008). Functional and Edible Uses of Soy Protein Products. Comprehensive review in food science and safety, 7, 14-28.

UNICEF. (2013). The right ingredients: The need to invest in child nutrition. London - United Kingdom: UNICEF.

USDA. (2013). National Nutrient Database for Standard Reference Release 26. USDA, Agricultural Research Service. www.ars.usda.

Young, V. R., \& Pellett, P. L. (1994). Plant proteins in relation to human protein and amino acid nutrition. Am J Clin nutr., 59, 1203-1212. https://doi.org/10.1093/ajen/59.5.1203S

\section{Appendix}

The following protein quality indices were calculated from the data collected (FAO, 2007).

$$
\begin{gathered}
\text { Net Protein Retention Ratio (NPRR) }=\frac{\mathrm{g} \text { of weight gain }+\mathrm{g} \text { of wgt loss in PFD }}{\mathrm{g} \text { of protein consumed }} \\
\text { Food Efieciency Ratio (FER) }=\frac{\mathrm{g} \text { of weight gain }}{\mathrm{g} \text { of food consumed }} \\
\text { Apparent Protein (N) Digestibility }(\%)=\frac{\mathrm{I}-\mathrm{F} \times 100}{\mathrm{I}}
\end{gathered}
$$

True Protein (N) Digestibility $(\%)=\frac{I-\left(F-F_{O}\right) \times 100}{I}$ 


$$
\text { Faecal Protein }(\%)=\frac{F-F_{O} \times 100}{I}
$$

Where: $\quad \mathrm{I}=$ Nitrogen intake of the test diet

$\mathrm{F}=$ Faecal nitrogen loss on the test diet

$\mathrm{F}_{0}=$ Faecal nitrogen loss on a protein-free diet

\section{Copyrights}

Copyright for this article is retained by the author(s), with first publication rights granted to the journal.

This is an open-access article distributed under the terms and conditions of the Creative Commons Attribution license (http://creativecommons.org/licenses/by/4.0/). 